\title{
Migration, Trade, and Foreign Direct Investment in Mexico
}

\author{
Patricio Aroca and William F. Maloney
}

\begin{abstract}
Part of the rationale for the North American Free Trade Agreement was that it would increase trade and foreign direct investment (FDI) flows, creating jobs and reducing migration to the United States. Since poor data on illegal migration to the United States make direct measurement difficult, data on migration within Mexico, where census data permit careful analysis, are used instead to evaluate the mechanism behind predictions on migration to the United States. Specifications are provided for migration within Mexico, incorporating measures of cost of living, amenities, and networks. Contrary to much of the literature, labor market variables enter very significantly and as predicted once possible credit constraint effects are controlled for. Greater exposure to FDI and trade deters outmigration, with the effects working partly through the labor market. Finally, some tentative inferences are presented about the impact of increased FDI on Mexico-U.S. migration. On average, a doubling of FDI inflows leads to a 1.5-2 percent drop in migration.
\end{abstract}

"Mexico wants to export goods, not people."

—Former Mexican President Carlos Salinas de Gortari

Mexican President Carlos Salinas de Gortari promoted the North American Free Trade Agreement (NAFTA) partly on the grounds that it would reduce incentives for Mexicans to migrate north. While this rationale is intuitively appealing, several studies have suggested possible slips "twixt cup and lip." Razin and Sadka (1997) note that dropping the assumption of identical production technologies or permitting increasing returns to scale allows trade and migration to be complements rather than substitutes. ${ }^{1}$ Markusen and Zahniser (1999), drawing on models and empirical evidence by Feenstra and

Patricio Aroca is a professor and director of the Institute for Applied Regional Economy (IDEAR), at the Universidad Católica del Norte, Antofagasta, Chile; his email address is paroca@ucn.cl. William F. Maloney is lead economist in the Office of the Chief Economist for Latin America at the World Bank; his email address is wmaloney@worldbank.org. The research for this article was financed by the regional studies program of the Office of the Chief Economist for Latin America at the World Bank. The authors thank Jaime de Melo, Gordon Hanson, and Raymond Robertson for insightful comments and Gabriel Montes Rojas and Lucas Siga for expert research assistance.

1. More generally, Faini (2004) notes the complex feedback among trade, FDI, and migration that can obscure the final impact on migration of liberalizing one sector. See also Faini, Grether, and De Melo (1999).

THE WORLD BANK ECONOMIC REVIEW, VOL. 19, NO. 3, pp. 449-472

doi:10.1093/wber/lhi017

Advance Access publication December 14, 2005

(C) The Author 2005. Published by Oxford University Press on behalf of the International

Bank for Reconstruction and Development / THE WORLD BANK. All rights reserved. For permissions, please e-mail: journals.permissions@oxfordjournals.org. 
Hanson (1995) and Markusen and Venables (1997), suggest that the foreign direct investment (FDI) and trade effects of NAFTA are likely to increase the relative earnings of skilled workers but not those of unskilled workers, who are most likely to migrate. Much of the migration literature has failed to find a significant impact on migration of wages or unemployment rates in the initial location (Greenwood 1997; Lucas 1997), casting some doubt on the strength of any trade or FDI effects working through the home country labor market. Perhaps most worrisome, there is increasing evidence that liquidity constraints are a barrier to migration-it takes resources to move (Stark and Taylor 1991). If FDI or trade flows relax this constraint, however, the expected substitution effect may be partially or completely offset, leading to more migration (López and Schiff 1998).

The illicit nature of Mexican-U.S. migration flows means that they are poorly measured. Thus, indirect approaches are needed. A small detailed case study literature on individual municipalities offers some suggestive evidence that NAFTA-related phenomena-female manufacturing employment and proximity to a maquila-might reduce migration. ${ }^{2}$ In a times-series context, Hanson and Spilimbergo (1999) find that border apprehensions are responsive to U.S.Mexico wage differentials, a finding confirmed by McKenzie and Rapoport (2004) using a retrospective survey. Davila and Saenz (1990) find a negative relationship between lagged maquila employment on the border and monthly border apprehensions as a proxy for migration pressures. Unfortunately, more direct data on FDI and trade with adequate periodicity or span are unavailable to offer enough degrees of freedom to permit inference with any confidence. Further, the massive peso crisis beginning roughly with the signing of NAFTA led to a sharp spike in unemployment and a 25 percent drop in wages. These likely induced migration flows to the United States that complicate inference on the more modest effects that NAFTA might have had in the opposite direction.

For these reasons, this article focuses on the mechanisms through which NAFTA-related variables might work, using data on migration flows within Mexico, across its 32 states. The 2000 census data permit careful analysis, and the 32 by 32 permutations offer substantial degrees of freedom.

A casual look at maps showing rates of net migration (net flows as a share of the population in the initial period) by state (figure 1) and FDI by state (figure 2) suggests a relationship between the magnitude of FDI and migration. By more rigorously investigating this possibility for FDI and other trade variables, this article makes three contributions to the literature on migration generally and, more specifically, on the impact of trade and FDI flows on migration.

2. Using data gathered in 25 Mexican communities, Massey and Espinosa (1997) create histories of migrants to the United States and find initial migration to be negatively related to the wage rate and the proportion of women in manufacturing. Jones (2001) examines 17 emigrant municipalities and argues for an association between proximity to maquiladoras and employment growth and, in turn, declining migration to the United States. 
Figure 1. Net Migration in Mexican States, 2000

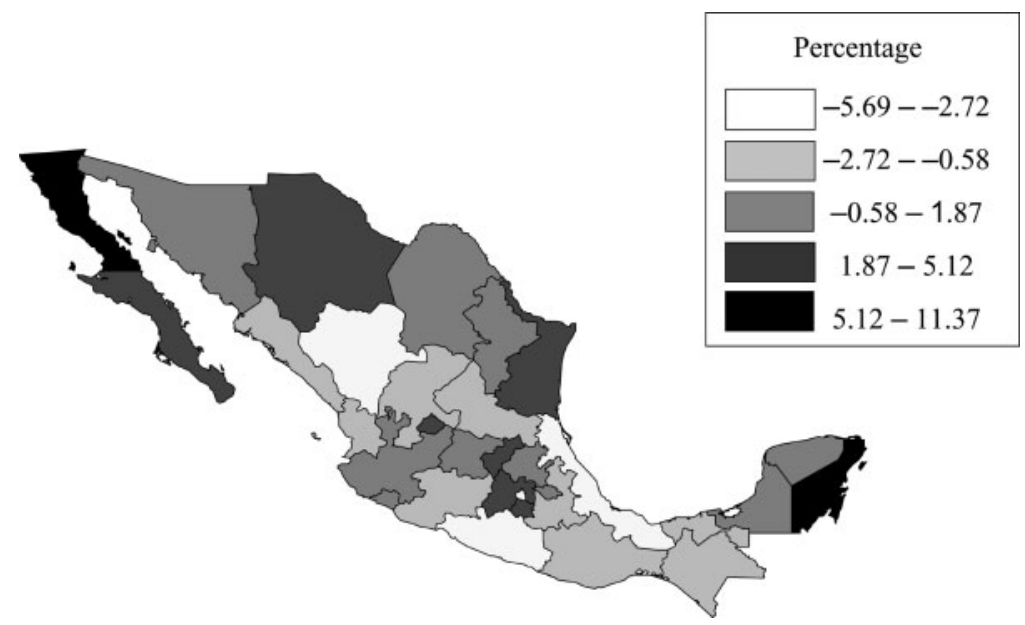

Source: General Census of Population and Housing 2000.

Figure 2. Foreign Direct Investment per Capita by Mexican States, 1994-2000

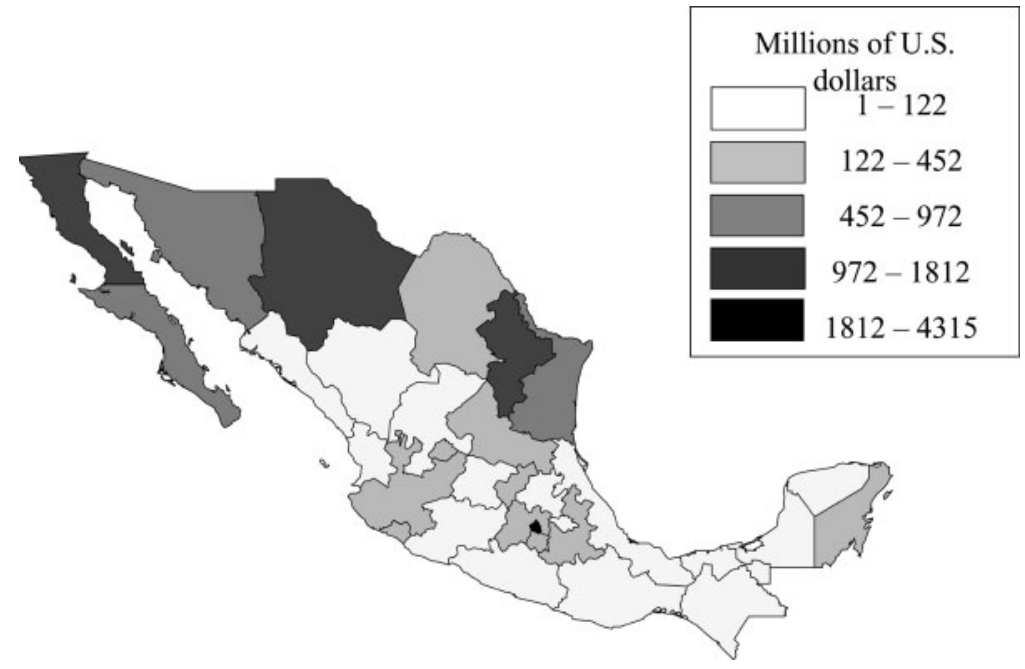

Source: Central Bank of Mexico.

First, the analysis produces the first estimates of determinants of migration flows within Mexico and advances the literature on developing country migration. In line with recent innovations in the literature on industrial countries, the analysis generates proxies for the level of amenities and costs of living and finds their influence to be statistically significant. Further, contrary to much of the literature 
for both industrial and developing countries noted above, the specification applied here allows disentangling the relative expected earnings effect from the liquidity effect. The results are highly significant, with intuitively plausible signs on labor market variables. Finally, network effects are introduced and also found to be strongly significant.

Second, the article offers evidence that both FDI and trade variables are substitutes for labor flows, are likely to work through the labor market, and have substantial deterrent effects. Even without the application to international migration, this finding is of intrinsic interest for the literature exploring the nexus of national spatial income disparities and migration (Barro and Sala-Martin 1992; Gabriel, Shack-Marquez, and Wascher 1993; Esquivel 1997) and the literature on how trade liberalization may affect regional disparities (Hanson 1997; Aroca, Bosch, and Maloney forthcoming). However, by establishing that the mechanisms through which NAFTA was expected to affect migration indeed function at the domestic level, the article supports President Salinas's claim for international migration as well. Further, the analysis implicitly addresses Markusen and Zahniser's (1999) concern that the skills demanded by FDI and trade are higher than those possessed by the majority of migrants to the United States and hence that NAFTA may have no effect. Finally, the results are also consistent with Robertson's (forthcoming) that trade is a force for wage convergence between the United States and Mexico more generally.

Third, the article offers some tentative back of the envelope inferences about the impact on Mexico-U.S. migration, implicitly treating the United States as the 33rd Mexican state. The magnitude of the impacts are found to be significant.

\section{Methodology}

A potential migrant faces $j$ possible destinations, where $i$ is the region of origin and $k$ is the migration region chosen, so that a worker's internal migration decision is reflected by the sign of the index function:

$$
I^{*}=V_{k}-V_{i}-C \text {. }
$$

where $V$ is an indirect utility function in the context of random utility theory (Domencich and McFadden 1975; Train 1986) and $C$ is a measure of costs. Utility is a function of a linear combination of location characteristics $X$.

$$
V_{j}=X_{j} \beta+\varepsilon_{j}
$$

If a migration destination is more desirable than the origin location, measured along several dimensions, and if the migrant has sufficient resources to move, then migration should occur. The probability that the indicator will be larger than zero is equal to the probability that the difference between $V$ s is greater than transport costs:

$$
P\left(I^{*}>0\right)=P\left(V_{k}-V_{t}-C>0\right)=P\left(\varepsilon_{i}-\varepsilon_{k} \leq X_{k} \beta-X_{i} \beta-C\right) .
$$


This specification nests many standard estimated functions (Greenwood 1997) including Borjas' (1994, 2001), where the only argument in the utility function is the wage. ${ }^{3}$ The actual specification depends on the assumptions about the error term.

The $\beta$ s may be allowed to vary, and in fact the literature tends to find a greater role for destination variables than for origin variables. This may be because of asymmetric information about locations (Gabriel, Shack-Marquez, and Wascher 1993) or because the individual variables are correlated with omitted variables that may have a greater impact on one end of the migration move. As discussed in more detail later, many variables could be correlated with unmeasured wealth or liquidity, which would determine whether the worker has the savings to pay the fixed cost of moving, $C$.

The matrix $X$ contains the variables capturing the relative expected incomes, $Y$, in the two areas (wages, unemployment, and price indices) and the set of characteristics of the two areas (amenities) that may also affect the migration decision. Any impact of FDI and trade would be expected to occur through $Y$.

Following Ben-Akiva and Lerman (1985), as generalized in Gourieroux (2000), for aggregate data:

$$
F^{-1}\left[P\left(I^{*}>0\right)\right]=X_{k} \beta_{d}-X_{i} \beta_{o}-C .
$$

where $F$ is the probability function that is determined by the structure of the errors.

The overall approach is to estimate a broadly standard specification augmented by some additional proxies and modified to better capture liquidity effects. Integration-related variables are then introduced to explore the degree to which their effects are channeled through the labor market.

\section{DAtA}

Data were collected on migration specifications and on trade and investment flows. Data sources and shortcomings are described in the following sections. None of the variables is ideal, but they are complementary in the sense of some being strong where others are weak. Together, this may provide a reliable picture of the impact of trade and investment variables.

\section{Migration Specifications}

Data were collected on interstate migration flows, moving costs, networks, population by state, labor markets, cost of living, and amenities.

3. Borjas (2001) argues that $I^{*}={ }_{j}^{\max }\left\{w_{j}\right\}-w_{i}-C$, where $I^{*}$ is an indicator variable, $w$ is the wage, and $C$ is the cost of transportation to the new location. This function must satisfy $w_{k}=\max _{j}\left\{w_{j}\right\}$, where $j$ represents all possible destinations, $i$ the region of origin, and $k$ the chosen destination. For other recent approaches to migration questions, see Davies, Greenwood, and Li (2001); Dahl (2002); and Ham, Li, and Reagan (2004). 
Migration Flows. The 2000 General Census of Population and Housing generates migration data from a question that asks in what state the interviewee resided five years earlier. Though this approach is standard, it has the drawback of failing to count migrants who may have left and returned over the five-year period. Flows to the United States are derived from a question asking whether a member of the household has gone to the United States in the last five years.

Moving Costs. Following the literature (see Greenwood 1997), the costs of transportation are approximated by a quadratic function of distance. ${ }^{4}$ This proxy for the costs of migration includes moving costs; the opportunity costs of moving, which rise with the length of the journey; and rising communication costs with the family in the point of origin, including the increased costs of return visits. In general, the literature expects a negative impact on migration but with decreasing effect.

NeTworks. An emerging literature stresses the importance of existing diaspora networks for lowering transaction and information costs. The Mexico-U.S. literature has particularly expanded on this point (see Zabin and Hughes 1995; Massey and Espinosa 1997; Winters, de Janvry, and Sadoulet 2001; McKenzie and Rapoport 2004). As in the literature on within-country migration, the share of the population that arrived in destination $j$ more than five years earlier and that was born in state of origin $i$ is used as a proxy for networks.

Population. Population by state in 1995 is taken from the census. As Greenwood (1997) summarizes, population is often used as a measure of the availability of public goods. However, larger states offer more potential matches than small states and so, in a random reallocation, will attract more migrants. Shultz (1982) also argues that larger states may have smaller rates of outmigration simply because there are more places to migrate to within the state. The 1995 value is used to eliminate any problems of simultaneity with migration flows in subsequent years.

LABOr Markets. The unemployment rate and nominal wage variables are generated as the average of their quarterly values in 1995, 1996, and 1997 from the National Urban Employment Survey (ENEU).

Cost of Living. Though presumably a potential migrant focuses on real rather than nominal expected wages, the relevant deflator may not be that of the

4. Though the indirect utility function is assumed to be linear and the weight of each variable to be similar in each region, this assumption can be easy relaxed to differentiate the origin and destination parameters. 
destination place of work. For instance, a migrant who plans to retire in a lowcost area may conceivably generate real savings measured in the retirement destination faster by earning a lower real wage in a high-cost area than by continuing to work in the area of origin (see Lucas 1997 for a survey of this literature). Further, a high cost of living may point to a larger potential income over the long run even if that is not realized by the individual making the decision (Spencer 1989; Pagano 1990). Certainly, in an intertemporal context, taking a lower real wage in the United States is still likely to offer the migrant's descendents far better options than would have been available in Mexico. ${ }^{5}$

Official price indices for Mexican states do not allow cost of living comparisons across states. For this reason, two indices were created using the 1992 National Survey of Household Income and Spending (ENIGH). Since food generally constitutes a large share of the consumption basket in developing countries, a Laspeyres index of a consumption basket of 200 items is generated using the national average in 1992 for price and reference basket. The housing price index was created using hedonic prices for rented houses only and is analogous to housing indices used in the industrial country literature. Housing characteristics include number of rooms; presence of kitchen, bathroom, electricity, telephone, sewerage, and potable water; types of walls, floors, and ceilings; and community size. ${ }^{6}$ Both indices are included separately and as an average measure of the cost of living. They are included as freestanding variables to allow for the effects described above. The specifications with the most predictive power were those using an average measure, and these are the results reported here.

AmENities. Price indices may simply reflect amenities available in the destination area, implying a positive relation with migration decisions. Further, as Roback (1982) shows, amenities affect equilibrium wages as well and hence should be included as part of the net utility change in moving from one location to another. A measure of amenities across Mexican states was created by the National Institute of Statistics, Geography, and Informatics (INEGI) using the 2000 census. However, that measure includes indicators of labor market tightness as well as migration variables (share of resident population born in other states and share residing in other states)—variables whose influence this analysis is trying to separate out. Therefore, a new index was created incorporating information on the share of the population living in urban areas, mortality rates, health infrastructure (number of nurses, doctors, hospitals per capita, and

5. The literature provides mixed evidence. Cameron and Muellbauer (1998), in studying UK migration, find strong "deflator" effects that they argue dominate any expectation effects. Thomas (1993), however, also looking at UK migration, finds no impact of regional house price difference on destination choice of any group except retirees.

6. The ENIGH includes information on house characteristics, which permit estimating housing costs. 
number of hospital beds), education (students per teacher in primary and secondary schools), and infrastructure (share of houses with electricity, share with sewerage). Four significant factor loadings were identified, with the first having the strongest interpretation as capturing amenities. The correlation of this measure with wages is 0.37 , and the correlation with the INEGI's welfare index is 0.77

\section{Trade and Investment Variables}

Data were collected on FDI, maquila value added, exports, and imports.

Foreign Direct Investment. Data on FDI per capita for 1995-99 are from the Central Bank of Mexico, as reported to the government by the investing firms. The Federal District of Mexico City shows vastly higher FDI rates than other states because much of the FDI destined for other states is registered at firms' company headquarters in Mexico City. A dummy variable is included in the regressions to account for this measurement error. As figure 2 suggests, FDI is highly concentrated along the northern border with the United States.

Maquila Value Added. The maquila value-added variable may be seen as a proxy for FDI, but since maquilas are primarily exporters, it can also be seen as a proxy for maquila exports per capita, which brings it closer to being a trade variable. Since the data are collected from industrial surveys, the variable does not suffer from the "headquarters" effect of the FDI variable. The two variables are moderately correlated (0.64), and so maquila value added may be a serviceable proxy for FDI more generally. One problem, however, is that the government of Mexico lumps data on maquila value added for 12 states into an "other" category, and the loss of data for these individual state implies reduced information and potential selection bias. The regressions are run with the substantially reduced sample.

EXPORTs. Data on exports are provided by the Ministry of Finance. As with the FDI data, the exports reported by firms are assigned to their headquarters location, often the Federal District of Mexico City, which may not be the actual location of production. The ministry therefore reassigns each firm's aggregate exports proportionally, using data on the location of plants and number of employees from the Mexican Institute of Social Security (IMSS) database. The methodology does not include oil or electricity exports and may miss smaller firms that do not register with IMSS.

IMPORTS. Import data came from Bancomex. This variable could have multiple and conflicting effects. It could simply reflect a state's degree of integration with external economies and hence be a proxy for exports. But if imports are seen as representing competition to import-substituting firms, the short-run labor market impact could be negative and hence imports could conceivably lead to more migration. 


\section{RESUlts}

Preliminary regressions estimated a multinomial logit model for aggregate data. Though the results were plausible, the Fry and Harris (1998) test suggests that the data violate the independence of irrelevant alternatives principle. Thus a multinomial probit model was estimated following Gourieroux's (2000) weighted least squares procedure. Summary statistics are provided in the appendix.

Overall, the specifications are very satisfactory, with the coefficients on the core variables generally statistically significant and of the predicted sign (table 1). The costs of movement variables-distance and network-are significant in all specifications, and the coefficients for distance are well within the usual range found in the literature (Greenwood 1997; see also Fields 1982; Shultz 1982; Gabriel, Shack-Marquez, and Wascher 1993). The population of the destination location is significant with a positive sign in all specifications, a result consistent with a connection point interpretation, a residuals amenity effect, or perhaps congestion externalities. The coefficient on the origin population is unstable across specifications.

The cost of living variable enters very significantly and is of important magnitude in the location of origin. The strong positive coefficient on the destination cost of living variable is unexpected. That may perhaps be consistent with cost of living being a measure of expectations of future income growth, as discussed earlier. Alternatively, as with many of the explanatory covariates, the cost of living is likely to be endogenous to immigration flowsa growing population pushes up the cost of housing, goods, and services-and therefore potentially biased. However, the lack of credible instruments precludes attempts to deal with simultaneity bias, so this possibility is posited as a caveat.

There appears to be some interaction between the amenities and network variables. In specifications without the network variable, the amenities variable enters with predicted sign, but the relative and freestanding specifications suggest that amenities may be correlated with an omitted credit constraint variable. Including the network term reduces the significance of the relative amenities term in virtually all specifications. The reason is not clear, although it may be that the cumulative migration from origin to destination state represented by the network term is especially related to relative amenities.

\section{Labor Market Variables}

Preliminary estimations $1 \mathrm{a}$ and $1 \mathrm{~b}$ (see table 1) found both unemployment and wage level in the origin state to be insignificant, as has frequently been found in the literature (Greenwood 1997; Lucas 1997). Attempts were made to isolate two countervailing effects, one a substitution effect among states and the other a wealth or liquidity effect that allows a potential migrant to cover the fixed cost of moving. This second effect has been found for U.S. unemployment by Goss and Schoening (1984) and Herzog, Schlottmann, and 


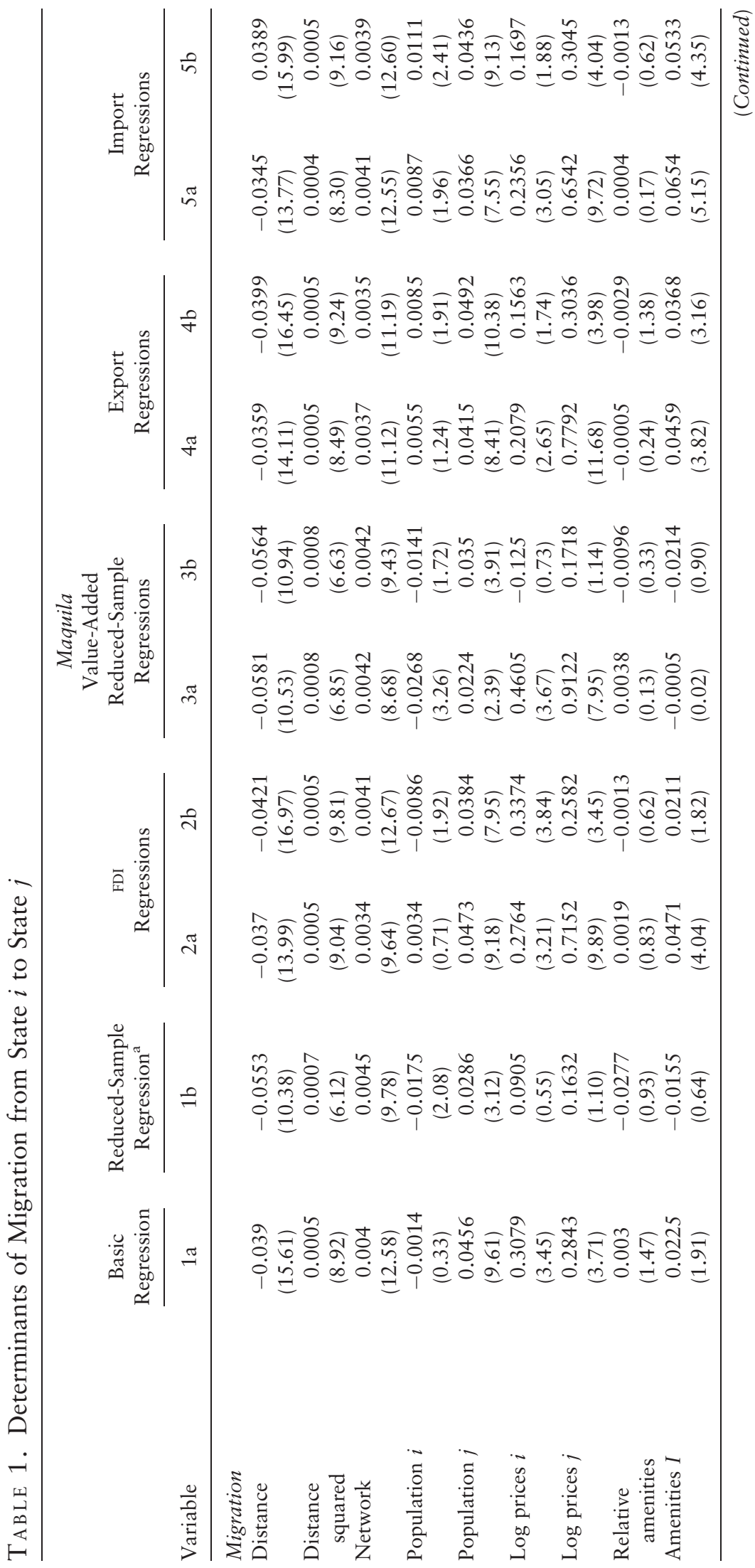




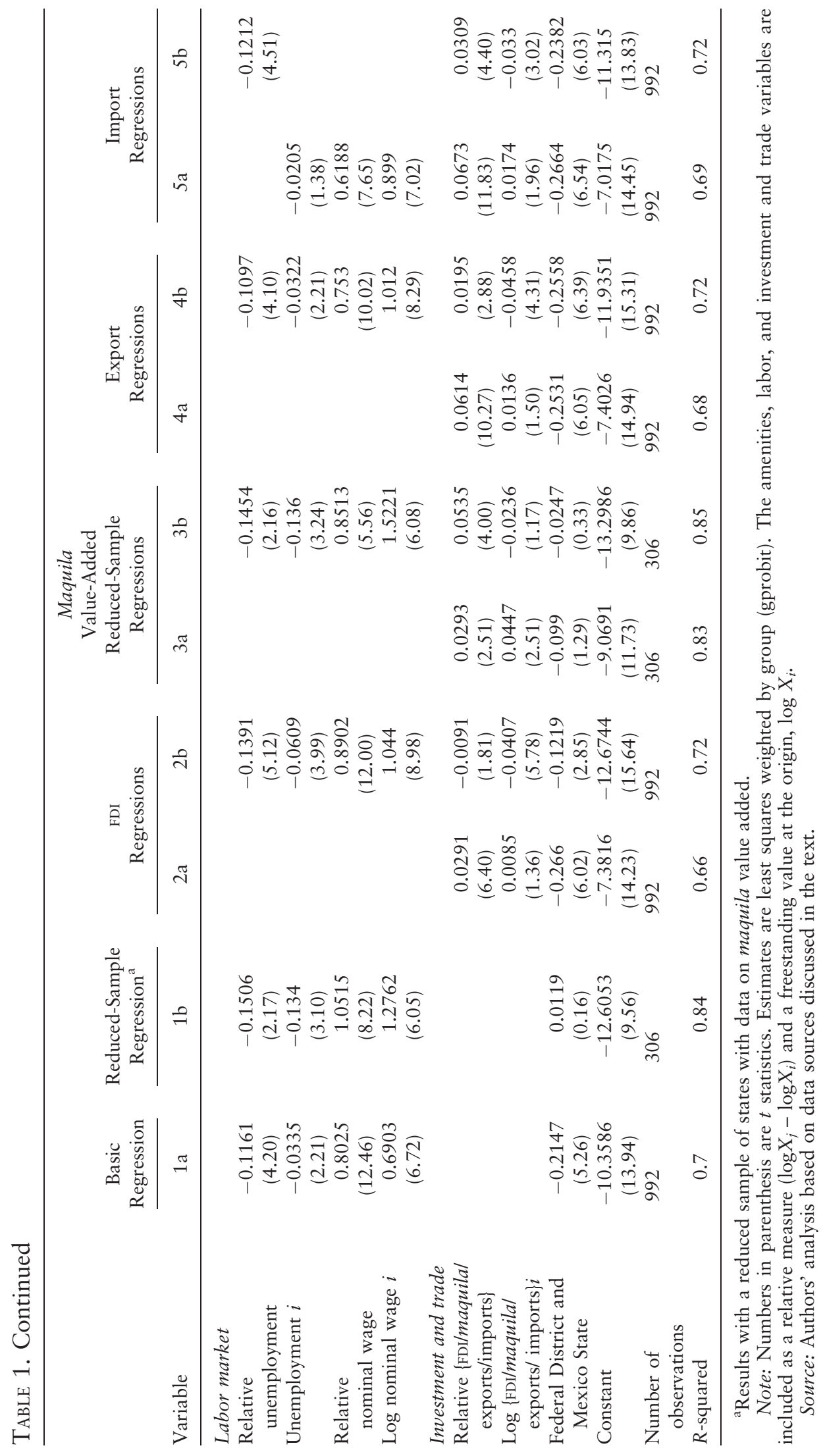


Boehm (1993), who find that the probability of moving decreases with the duration of unemployment. The literature on the wage effect is also extensive. (Stark and Taylor 1991 discuss credit constraints.) Relative wage $\left(\ln w_{j}-\ln w_{i}\right)$ and relative unemployment $\left(U_{j} / U_{i}\right)$ variables capture substitution effects, and freestanding initial wage and unemployment variables capture credit constraint effects. In the complete sample all but freestanding unemployment enter significantly, while in the restricted sample regression the coefficient has the predicted sign and is significant at the 10 percent level. This overall strong performance suggests that the poor results for origin labor market variables in many previous studies arise precisely because they capture two contradictory tendencies.

\section{Integration Variables}

Four specifications drop the labor force variables and replace them with the trade and investment variables, again in relative and freestanding form (table 1, columns $2 \mathrm{a}, 3 \mathrm{a}, 4 \mathrm{a}$, and $5 \mathrm{a}$ ). In all cases there is evidence of a strong substitution effect: FDI and trade reduce migration. The freestanding term is significant in half the cases, consistent with López and Schiff's (1998) concern that trade and investment integration may increase migration flows by releasing liquidity and wealth constraints. In the case of maquilas and imports, this liquidity effect appears to offset to some extent the substitution effect found with the relative term.

When the labor force variables are added, the results suggest that some of the effects of the trade and investment variables work through the labor market (table 1, columns $2 \mathrm{~b}, 3 \mathrm{~b}, 4 \mathrm{~b}$, and $5 \mathrm{~b}$ ). This interpretation is consistent with Hanson's (forthcoming) finding that the distribution of conditional labor income was shifted to the right in states with high exposure to similar trade and investment variables relative to states with low exposure. The substitution effect diminishes by at least a factor of 2 in most cases and in the case of FDI becomes insignificant. The exception is the maquila variable, which appears to strengthen. Whether this is due to the selection bias caused by the grouping of official data for states with a small maquila presence is not clear.

The freestanding trade and investment variables also show a propensity to flip sign in all cases, suggesting that they were capturing the initial wealth and liquidity now captured by initial wages and unemployment. Minus this effect, the deterrent effect of the trade and investment variables is more powerful than the attraction effect of the destination. The fact that all relative trade and investment variables retain an effect outside of the contemporaneous labor market variables may reflect an independent disincentive effect to migrate, perhaps through expectations of future growth. In all cases the possible endogeneity between local labor market variables and the location of trade and FDI is left largely unexplored due to the lack of credible instruments. Further, it is possible that both migrants and FDI are attracted by the same characteristics, an issue at least partially addressed by the invariance of the results to the inclusion 
Figure 3. Estimated Migration Push and Pull Elasticities to Foreign Direct Investment by State

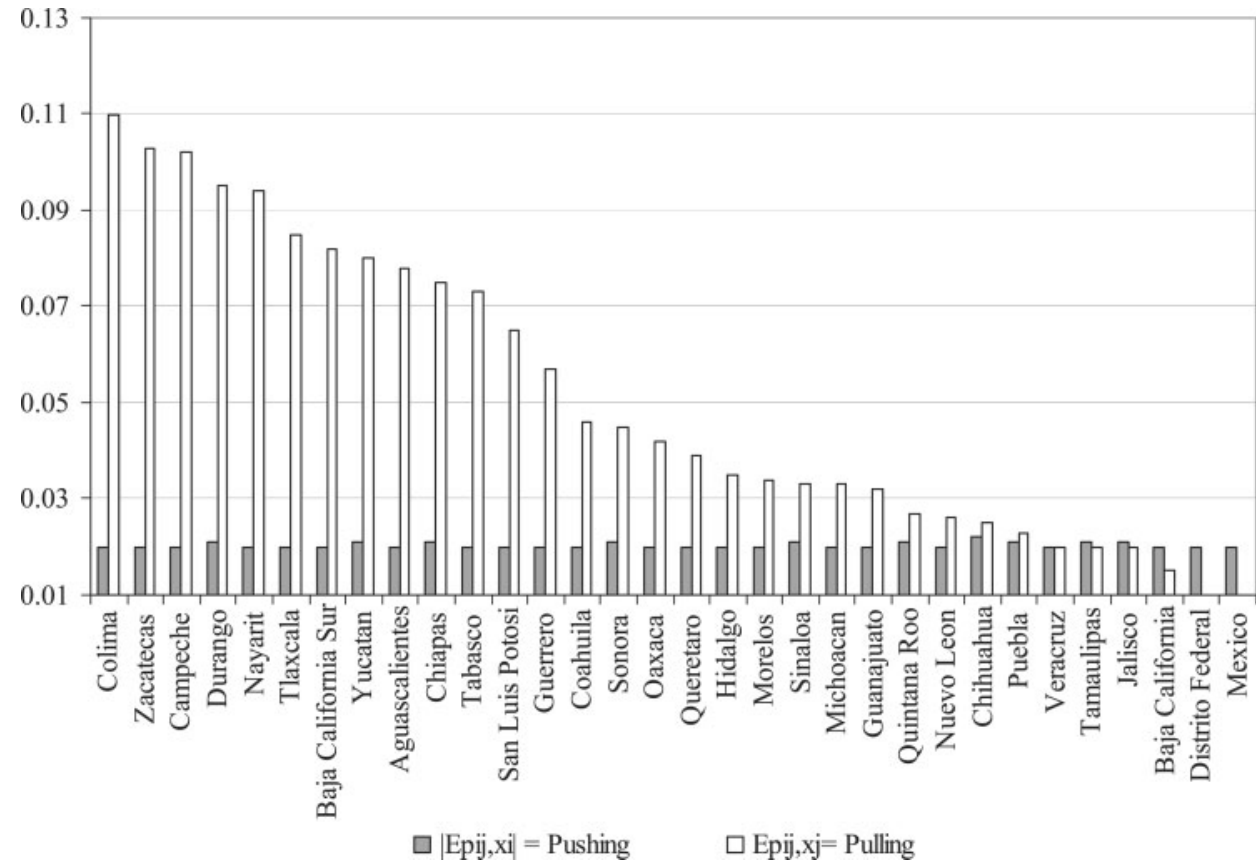

Source: Authors' analysis based on data sources discussed in the text.

of fixed effects. ${ }^{7}$ For these reasons, the results may suggest that part of the impact of these variables on migration works through the labor market.

As an example of the implied magnitudes, estimated migration elasticities in response to an increase in FDI were calculated by state for both a reduction in push migration forces from the state and an increase in pull forces from other states (figure 3). Though in theory the liquidity effect identified in the maquila and export cases could dominate and cause an increase in push migration, in the FDI case the coefficient is small and insignificant, and push forces are clearly reduced in all states with elasticities averaging 0.02 . Pull elasticities are

7. Two more variants of the base and FDI regressions were run as additional robustness tests. One regression, which included a full set of state dummy variables, both origin and destination, showed the predictable effects of the substantially reduced degrees of freedom but had relatively little effect on the magnitudes of the core variables. In the key specification on which the simulations are based (table 1, column 2 b), the relative FDI term changed little, falling from 0.029 to 0.021 and the $t$ statistic from 6.4 to 3.6. The freestanding term remained insignificant. A second regression included a measure of relative education levels, measured as average years of schooling. The relative and freestanding initial terms enter insignificantly and have little impact on the other covariates with the exception of a perhaps predictable slight lowering of the relative wage term and a rendering insignificant of the freestanding amenities term. 
Figure 4. Estimated Impact on Push and Pull Migration of a 10 Percent Rise in Foreign Direct Investment as a Share of Total Migration from State

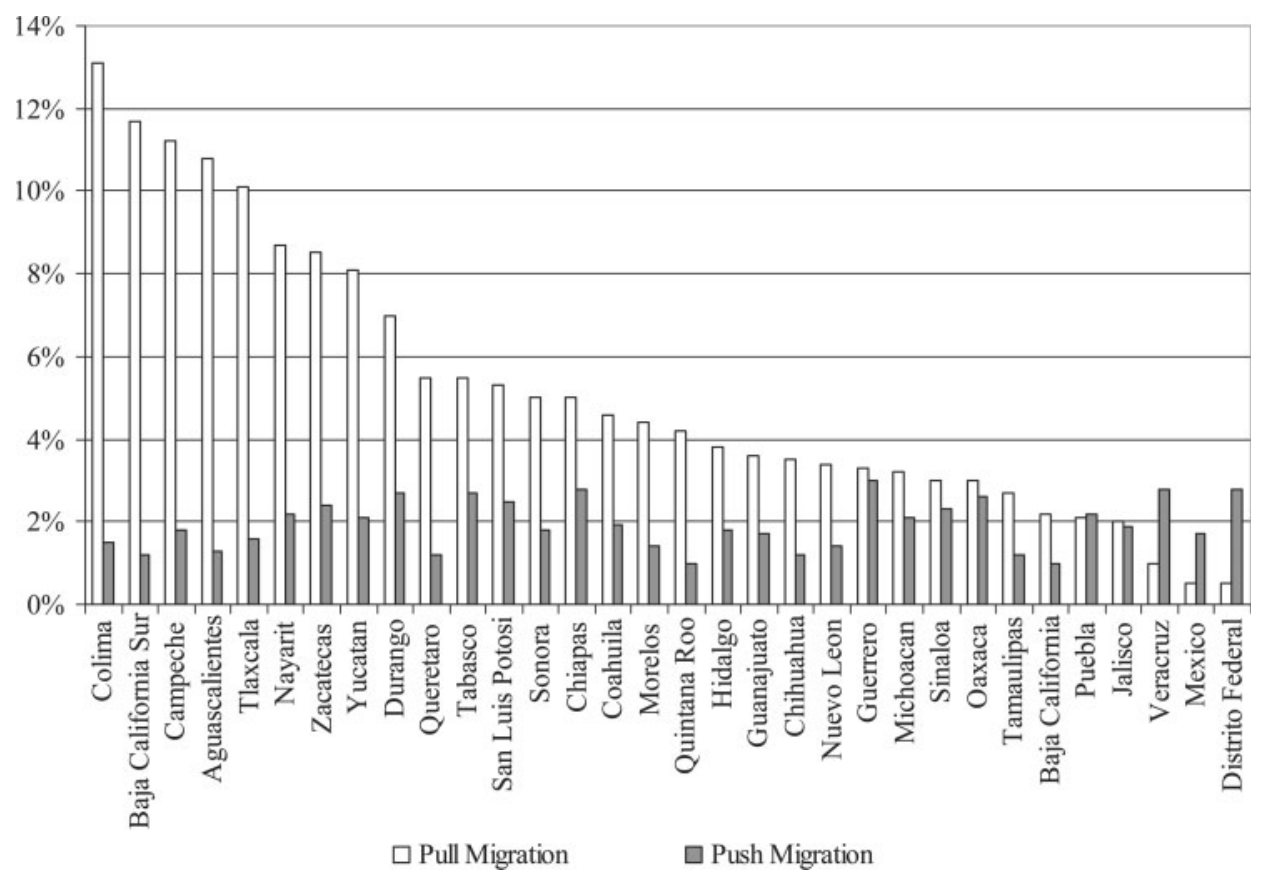

Source: Authors' analysis based on data sources discussed in the text.

substantially higher, averaging 0.05 and reaching as high as 0.1 in Colima, Zacatecas, and Campeche. A doubling of FDI in these states leads to a 10 percent increase in migrants attracted to the state and a 2 percent decline in outflows.

To see whether these magnitudes are important, the impact of a 10 percent rise in each state's FDI on the magnitude of push and pull migration forces is divided by total outmigration to the United States and to other Mexican states, as a measure of scale. Both effects are of nontrivial magnitude. Push migration falls by 1-3 percent of total migration, while the rise in pull migration ranges from under 0.5 percent to more than 10 percent in Colima, Zacatecas, and Campeche (figure 4). Inflows of FDI thus have a potentially substantial impact on migratory flows.

Further, Markusen and Zahniser's (1999) concern that FDI and trade would not prove a disincentive to migration because they do not affect the relevant migratory population is addressed by comparing the internal migrant population and the population migrating to the United States in educational attainment, age, and gender (table 2). ${ }^{8}$ Men in the two populations have similar 


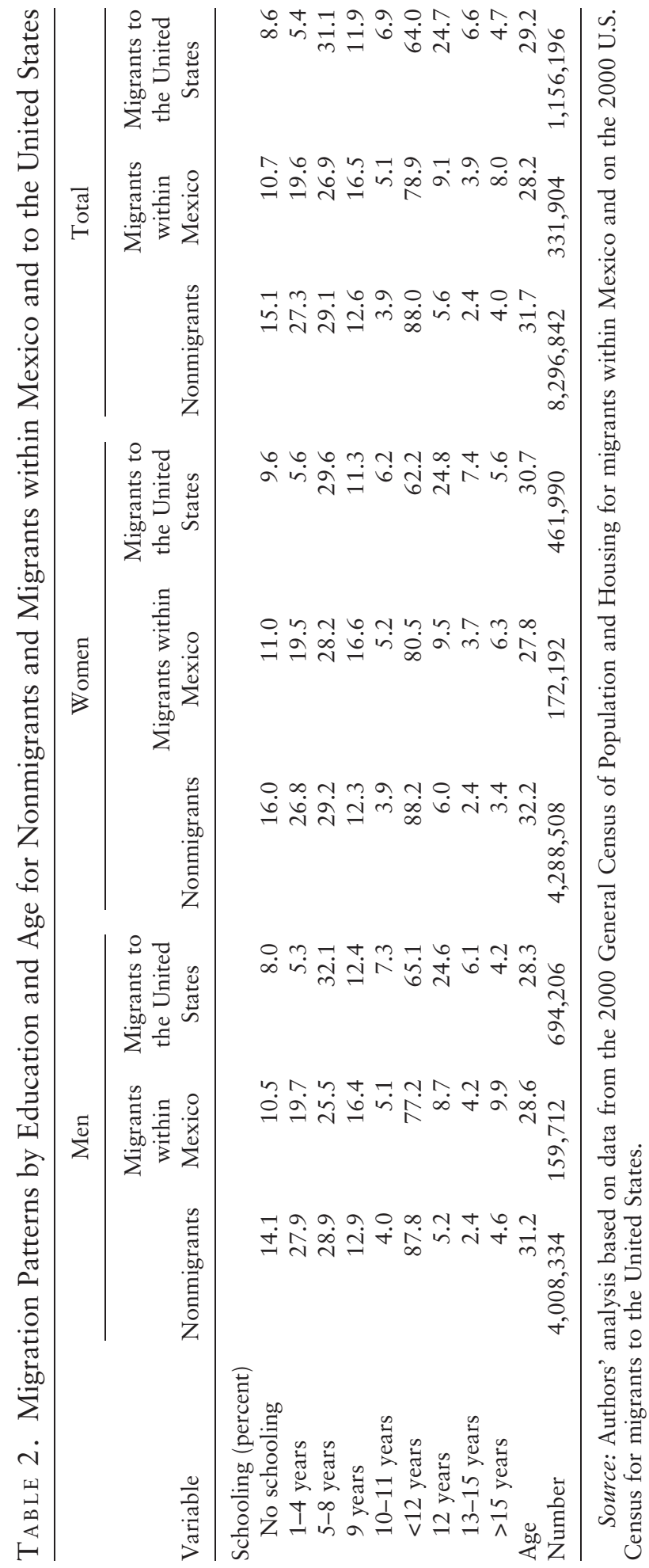


age profiles, although women who migrate to the United States tend to be somewhat older than women who migrate internally, perhaps reflecting delayed migration to the United States after their spouse. A key finding among both men and women, however, is that domestic migrants are somewhat less educated than migrants to the United States, suggesting that Markusen and Zahniser's concern is unfounded.

\section{Simulations of the Impact on Migration to the United States}

Ideally, the estimates for internal migration could be used to approximate the magnitude of the impact on migration to the United States. Clearly, for such an exercise to be valid, the types of people who decide to migrate to the United States must not differ too much from those who decide to migrate within Mexico, or, put differently, the factors motivating the decision to migrate must not differ too much between the two destinations. As discussed, the demographics of the two groups are similar (see table 2). While the literature is mixed, it is not necessarily inconsistent with this assumption. ${ }^{9}$ It does appear, however, that women are more likely than men to migrate within Mexico rather than to the United States. This may reflect a household strategy of migrating to the border region and sending the husband across to the United States to engage in the riskier and more intensive work, while the wife stays on the Mexico side of the border working in less risky, less demanding jobs that permit easier balancing of family responsibilities (Zabin and Hughes 1995). The literature stresses the importance of accumulated networks, which appear to have caused some Mexican states to generate a disproportionate number of U.S.-bound migrants. To the extent possible, the domestic regressions control for such effects, and as detailed below, additional adjustments were made in the simulations.

A second concern is whether the U.S. variables are too "out of sample" to permit treating the United States as a 33rd Mexican state. The ratio of the per capita income of Mexico's richest state, the Federal District of Mexico City, relative to its poorest state, Chiapas, is about 6.4 in nominal terms and 5.6 in real terms, while the ratio of the average for the United States relative to Mexico

9. Rivera-Batiz (1986, p. 265), in an often-cited article, implicitly suggests migrants' indifference between destinations: "The impact of the maquiladoras on migration to the United States is dependent on whether they are able to raise employment by more than they increase the labor supply in the border areas through induced migration from southern regions. If an excess supply of labor is generated at the border with surplus workers becoming either openly unemployed or underemployed, it is likely that there will be a spillover into illegal migration to the United States." The fieldwork on "staged migration" can be read both ways. On the one hand, workers in the first stage, moving, for instance, from Oaxaca to jobs in Baja California, have less information and capital and fewer contacts than workers who decide to make a second-stage crossing to the United States. On the other hand, the underlying objective function is arguably the same for both workers, and migration costs (embodied in information or networks) and credit constraints are standard in the migration specifications. See Durand and Massey (1992) for a review of the field literature on migration and Cornelius and Martin (1993) and Zabin and Hughes (1995). 
Table 3. Monthly Wages and GDP per Capita, Mexico and United States

\begin{tabular}{|c|c|c|c|}
\hline \multirow[b]{2}{*}{ Item } & \multicolumn{2}{|r|}{ Mexico } & \multirow[b]{2}{*}{$\begin{array}{c}\text { United States } \\
\text { (Current U.S. Dollars) }\end{array}$} \\
\hline & $\begin{array}{l}\text { Current U.S. } \\
\text { Dollars }\end{array}$ & $\begin{array}{c}\text { Purchasing Power } \\
\text { Parity (U.S. Dollars } \\
\text { Adjusted by State CPI) }\end{array}$ & \\
\hline \multicolumn{4}{|l|}{ GDP per capita } \\
\hline Average & 5,393 & 8,349 & 29,451 \\
\hline Minimum & 2,368 & 3,617 & 20,856 \\
\hline Maximum & 15,226 & 20,268 & 40,870 \\
\hline $\begin{array}{l}\text { Ratio of maximum } \\
\text { to minimum }\end{array}$ & 6.4 & 5.6 & 2.0 \\
\hline $\begin{array}{l}\text { Ratio of average U.S. } \\
\text { to Mexican maximum }\end{array}$ & 1.9 & 1.5 & \\
\hline \multicolumn{4}{|l|}{ Monthly wage } \\
\hline Average & 372 & 575 & 1,716 \\
\hline Minimum & 218 & 375 & \\
\hline Maximum & 551 & 825 & \\
\hline $\begin{array}{l}\text { Ratio of maximum } \\
\text { to minimum }\end{array}$ & 2.5 & 2.2 & \\
\hline $\begin{array}{l}\text { Ratio of average U.S. } \\
\text { to Mexican maximum }\end{array}$ & 3.1 & 2.1 & \\
\hline
\end{tabular}

Source: Authors' calculations based on data from the Mexican National Urban Employment Survey, National Institute of Statistics, Geography, and Informatics, U.S. Bureau of Economic Analysis (http://www.bea.doc.gov ), and U.S. Bureau of Labor Statistics (http://www.bls.gov/cps/ cpsaat37.pdf). See text for details.

City is only about 1.9 , or 1.5 in purchasing power parity terms adjusted by the state consumer price index (table 3). That is, in terms of development the United States is closer to Mexico City than Mexico City is to Chiapas. Nor are wage differentials radically different. The ratio of the Hispanic real wage in the United States to the mean wage of Mexico City adjusted for purchasing power parity is roughly the same as the ratio of the real wage in Mexico City to that in Chiapas.

There may be some concern that the importance of the U.S. border is not well represented by the transport costs variable. In fact, there is strong evidence that the cost of border crossing is more a difference in magnitude than in kind. Donato, Durand, and Massey (1992, pp. 152, 155) argue that "our data from Mexico reveal a fairly high probability of apprehension by [the U.S. Immigration and Naturalization Service] combined with a near-certain probability of ultimately entering the United States" and that "every migrant who attempted a border crossing, whether apprehended or not, eventually gained entry" [italics in original]. This suggests that border control serves more as a tariff than a quota.

The costs of moving across states or to the United States are substantially different, but perhaps not as different as might at first be thought. In 2002 the cost of second-class bus fare from Quintana Roo to Coahuila, one of the longer 
trips in the sample, was roughly US\$100, whereas transportation between Mexico State and Mexico City cost very little. ${ }^{10}$ Anecdotal evidence puts the cost of direct transportation across the border in the 1980s at US\$150 (US\$244 in 2002; Conover 1987 cited in Hanson and Spilimbergo 1999), again, not so far out of sample. ${ }^{11}$ The cost of a smuggler-guide appears to have held steady in real terms since the 1960s at around US\$350 (US\$2,075 in 2002; Donato, Durand, and Massey 1992), ${ }^{12}$ although Crane and others (1990, as cited in Hanson and Spilimbergo 1999) suggest that only 8.3 percent of those apprehended in the United States in 1993 had employed one.

Despite some differences, therefore, the overall magnitudes of the migration variables for the United States and Mexican states are not "too different." Of total migration, roughly two-thirds is internal and one-third is to the United States. As a crude first approximation, making no adjustments for any likely covariates such as distance or relative wages, a simple $\chi^{2}$ statistic suggested by Bickenbach and Bode (2003) cannot reject the hypothesis that the same Markov process is driving both United States and intra-Mexican migration for 12 of the 32 states. $^{13}$

To generate back of the envelope calculations, note first that total emigration from any state is the sum of migration to other states plus to the United States:

$$
\begin{aligned}
& M_{i}=\sum_{j=1}^{32} m_{i j}+m_{i \mathrm{US}} \text { for all } i=1, \ldots, 32 \\
& M_{i}=\sum_{j=1}^{32} \operatorname{Pop}_{i}^{*} p_{i j}+m_{i \mathrm{US}} .
\end{aligned}
$$

Total migration in Mexico is

$$
M=\sum_{i=1}^{32}\left(m_{i \mathrm{US}}+\operatorname{Pop}_{i} \sum_{j=1}^{32} p_{i j}\right)=M_{\mathrm{US}}+\sum_{i=1}^{32}\left(\operatorname{Pop}_{i} \sum_{j=1}^{32} p_{i j}\right)
$$

where $M_{\mathrm{Us}}$ is total migration from Mexico to the United States. As shown above, the probability of migrating from state $i$ to state $j$ depends on the characteristics

10. White Star Bus line.

11. Inflated from 1985 figure with CPI.

12. This showed little change with the Immigration Reform and Control Act of 1986, suggesting that it is a fairly robust number. The 2002 figure was reached by inflating the 1960 figure by the CPI. Smuggler-guides get paid only for successful crossings.

13. Mexico State and the Federal District are dropped from the sample since they are effectively the same unit and have very high flows between them. 
in $X, p_{i j}=\Phi(X \beta)$ and hence on $\Phi^{-1}\left(\hat{p}_{i j}\right)=z_{i j}=X b$. The percentage change in immigration to the United States is thus obtained from:

$$
\frac{\partial \ln M_{\mathrm{US}}}{\partial \ln X_{k}}=-\frac{1}{M_{\mathrm{US}}} \sum_{i=1}^{32} \operatorname{Pop}_{i} \sum_{k=1}^{32} \frac{\partial \Phi(X b)}{\partial \ln X_{k}}+\frac{1}{M_{\mathrm{US}}} \frac{\partial M}{\partial \ln X_{k}} \quad \text { for } k=\{i, j\} .
$$

The first term captures the substitution effect-how much existing migrant flows will be reallocated across destinations given the change in $X_{k}$. The second term captures the aggregate percentage change in migration, a component that cannot be captured from domestic data. Given the liquidity effect detected earlier, this variable has the potential to be positive. However, the liquidity effect was not significant in the FDI regressions, and there was no increase in outmigration for any state in response to FDI. Thus, the effects generated by the first term can be considered to offer a lower bound of the total effect on U.S. migration.

The estimator used in the previous regressions weighted all states equally, beyond the necessary correction for heteroskedasticity brought on in the binomial context by differential state sizes (Domencich and McFadden 1975). This is not necessarily the case when estimating the function implicitly to include the United States as the 33rd state:

$$
\hat{P}_{i j}=\Phi(X \hat{\beta}) \quad \text { subject to } \sum_{j=1}^{32+\mathrm{USA}} \hat{P}_{i j}=1
$$

Clearly, the determinants of $\hat{P}_{i U S A}$ are lacking, but information is available on which states send more migrants to the United States, particularly those with long-established networks, which allows more precise estimation. The constraint can be easily rewritten as:

$$
\frac{1}{1-\hat{P}_{i \mathrm{USA}}} \sum_{j=1}^{32} \hat{P}_{i j}=1
$$

where the first term, a function of the share of each state that migrates to the United States, becomes the weight of the estimated function. In practice, the estimates differ somewhat, but not greatly, from the previous estimates.

The elasticity of migration to the United States with respect to FDI is quite low-on average, a doubling of FDI leads only to a 1.5-2 percent reduction in migration (figure 4). Further, for many states the impact of a single US\$100 million investment in a new plant reduces migration by very little (figure 5). However, in areas such as Veracruz, where there is little FDI and migration is high, the decline in outflows is substantial, in the case of a doubling FDI, approaching 4,000 people. 
Figure 5. Estimated U.S. Migration Elasticity to Foreign Direct Investment and Migration Response of a US\$100 Million Investment in the State

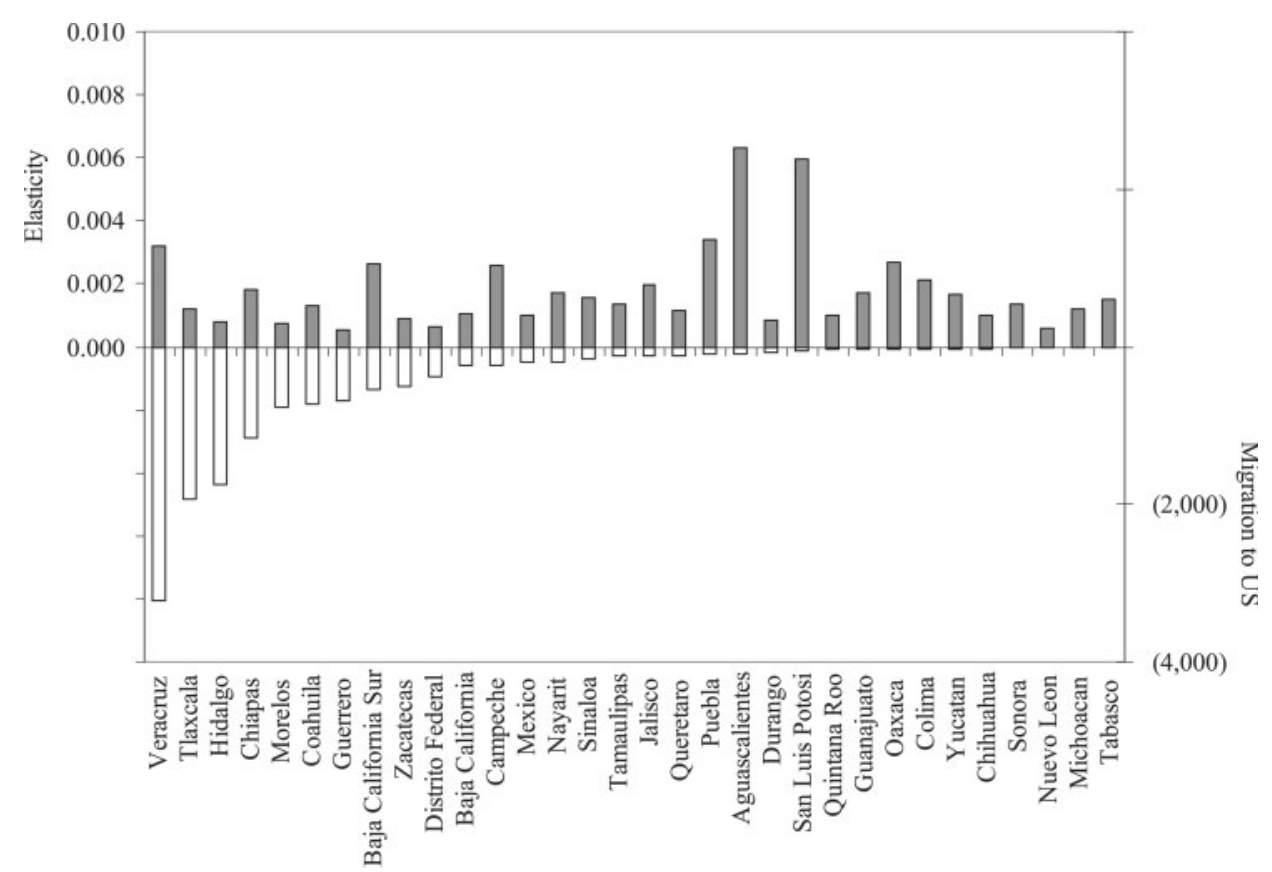

Source: Authors' analysis based on data sources discussed in the text.

Again, these are intended simply as back of the envelope calculations. They rely heavily on the assumption that the United States is considered broadly as the 33rd destination for a potential migrant. Further, since the analysis captures only the impact of the redirection of existing migration to other Mexican states, not the overall decline in migration, these results must be seen as lower bounds.

\section{Conclusions}

This article evaluated the mechanisms through which NAFTA-related variables might work to reduce migration to the United States, using data on migration within Mexico. The analysis makes three contributions to the literature on migration, especially the impact of trade and FDI flows on migration.

First, it offers the first estimates of the determinants of migration flows within Mexico and advances the migration literature on developing countries. In line with recent literature on industrial country migration, the analysis generates proxies for the level of amenities, costs of living, and networks and generally finds them to be significant. Contrary to much of the literature, the specifications 
here generate intuitive signs and significant results for origin state labor market variables: a rise in home earnings or employment levels deters migration. Part of the reason for the poor performance of place of origin variables in previous studies is that they capture a mix of deterrent effects and credit constraints.

Second, FDI, maquila value added, exports, and imports are substitutes for labor flows. They appear to work at least partly through the labor market, and their effects are substantial. Further, though there is evidence that greater investment or trade may release credit constraints and increase migration, as suggested by López and Schiff (1998), that effect does not dominate in the case of FDI examined here.

Third, the article generates some tentative inferences about the impact on Mexico-U.S. migration, treating the United States implicitly as a 33rd Mexican state.

\section{APPENDIX}

Table A-1. Summary Statistics te $j$

\begin{tabular}{|c|c|c|c|c|c|}
\hline Variable & $\begin{array}{l}\text { Number of } \\
\text { Observations }\end{array}$ & Mean & $\begin{array}{l}\text { Standard } \\
\text { Deviation }\end{array}$ & Minimum & Maximum \\
\hline $\begin{array}{l}\text { Migrants from } \\
\text { state } i \text { to state } j\end{array}$ & 992 & 3,890 & 17,208 & 16 & 470,693 \\
\hline Population & 992 & $2,848,697$ & $2,440,552$ & 375,494 & $11,170,796$ \\
\hline Distance & 992 & 19.27 & 12.42 & 1 & 64.88 \\
\hline Distance squared & 992 & 525.98 & 660.95 & 1.00 & $4,209.00$ \\
\hline Prices & 992 & 100.00 & 16.55 & 66.99 & 138.15 \\
\hline Log prices & 992 & 4.59 & 0.16 & 4.20 & 4.93 \\
\hline Unemployment & 992 & 2.99 & 1.04 & 1.46 & 6.64 \\
\hline Nominal wages & 992 & 1,787 & 345 & 1,208 & 3,036 \\
\hline Log nominal wages & 992 & 7.47 & 0.18 & 7.07 & 8.01 \\
\hline Amenities & 992 & 2.11 & 1.00 & 0.10 & 4.72 \\
\hline FDI & 992 & 268.00 & 386.00 & 0.04 & $1,617.00$ \\
\hline Log FDI & 992 & 4.35 & 2.15 & -3.11 & 7.38 \\
\hline Exports & 992 & 1,452 & 2,130 & 19.82 & 8,578 \\
\hline Log exports & 992 & 6.14 & 1.69 & 2.98 & 9.05 \\
\hline Imports & 992 & 844 & 1,219 & 5.52 & 4,176 \\
\hline Log imports & 992 & 5.51 & 1.84 & 1.7084 & 8.33 \\
\hline Maquila & 306 & 97,681 & 129,480 & 1,029 & 453,211 \\
\hline Log maquila & 306 & 10.57 & 1.51 & 6.93 & 13.02 \\
\hline
\end{tabular}

Source: Authors' analysis based on data sources discussed in the text.

\section{REFERENCES}

Aroca, Patricio, Mariano Bosch, and William F. Maloney. Forthcoming. "Spatial Dimensions of Trade Liberalization and Economic Convergence: Mexico 1985-2002.” World Bank Economic Review 19(3).

Barro, Robert J., and Xavier Sala-i-Martin. 1992. "Regional Growth and Migration: A Japan-United States Comparison." Journal of the Japanese and International Economies 6(4):312-46. 
Ben-Akiva, M., and S. R. Lerman. 1985. Discrete Choice Analysis. Theory and Application to Travel Demand. Cambridge, MA: MIT Press.

Bickenbach, F., and E. Bode 2003. "Evaluating the Markov Property in Studies of Economic Convergence.” International Regional Science Review 26(3):363-92.

Borjas, George. 1994. “The Economics of Immigration.” Journal of Economic Literature 32(4):1667-717.

- 2001. Does Immigration Grease the Wheels of the Labor Market? Brookings Papers on Economics Activity 1. Washington, D.C.: Brookings Institution.

Cameron, Gavin, and John Muellbauer. 1998. The Housing Market and Regional Commuting and Migration Choices. Discussion Paper 1945. London: Centre for Economic Policy Research.

Chiquiar, Daniel, and Gordon H. Hanson. 2003. International Migration, Self-Selection, and the Distribution of Wages: Evidence from Mexico and the United States. NBER Working Paper 9242. Cambridge, MA: National Bureau of Economic Research.

Conover, Ted. 1987. Coyotes: A Journey Through the Secret World of America's Illegal Aliens. New York: Vintage Departures.

Cornelius, Wayne A., and Philip L. Martin. 1993. "The Uncertain Connection: Free Trade and Rural Mexican Migration to the United States.” International Migration Review 27(3):484-512.

Crane, Keith, Beth J. Asch, Joanna Z. Heilbrunn, and Danielle C. Cullinane. 1990. The Effect of Employer Sanctions on the Flow of Undocumented Immigrants to the United States. Urban Institute Report 90-8. Washington, D.C.

Dahl, Gordon B. 2002. "Mobility and the Return to Education: Testing a Roy Model with Multiple Markets.” Econometrica 70(6):2367-420.

Davies, P. S., M. J. Greenwood, and H. Li. 2001. “A Conditional Logit Approach to U.S. State-To-State Migration." Journal of Regional Science 41(2):337-60.

Davila, Alberto, and Rogelio Saenz. 1990. “The Effect of Maquiladora Employment on the Monthly Flow of Mexican Undocumented Immigration to the U.S., 1978-1982.” International Migration Review 24(1):96-107.

Domencich, T.A., and D. McFadden. 1975. Urban Travel Demand. A Behavioral Analysis. New York: Elsevier.

Donato, Katharine M., Jorge Durand, and Douglas S. Massey. 1992. "Stemming the Tide? Assessing the Deterrent Effects of the Immigration Reform and Control Act.” Demography 29(2):139-57.

Durand, Jorge, and Douglas S. Massey. 1992. "Mexican Migration to the United States: A Critical Review." Latin American Research Review 27(2):3-42.

Esquivel, Gerardo Hernandez. 1997. "Essays on Convergence, Migration, and Growth.” PhD Dissertation, Massachusetts Institute of Technology, Cambridge, MA.

Faini, Riccardo. 2004. Trade Liberalization in a Globalizing World. Paper Presented at the Annual World Bank Conference on Development Economics-Europe, May 10-11, Brussels.

Faini, R., J.-M. Grether, and J. De Melo. 1999. "Globalization, and migratory pressures from developing countries: A simulation analysis.” In R. Faini, J. De Melo, and K. F. Zimmermann, eds., Migration: The Controversies and the Evidence. Cambridge: Cambridge University Press.

Feenstra, R. C., and G. H. Hanson. 1995. Foreign Direct Investment and Relative Wages: Evidence from Mexico's Maquiladoras. NBER Working Paper 5122. Cambridge, MA: National Bureau of Economic Research.

Fields, G. 1982. "Place-to-Place Migration in Colombia.” Economic Development and Cultural Change 30(3):538-58.

Fry, T. R. L., and M. N. Harris. 1998. "Testing for Independence of Irrelevant Alternatives. Some Empirical Results." Sociological Methods and Research 26(3):401-23.

Gabriel, S. A., J. Shack-Marquez, and W. L. Wascher. 1993. "Does Migration Arbitrage Regional Labor Market Differentials?” Regional Science and Urban Economics 23(2):211-33.

Goss, E. P., and N. C. Schoening. 1984. "Search Time, Unemployment, and the Migration Decision." Journal of Human Resources 19(4):570-9. 
Gourieroux, Christian. 2000. Econometrics of Qualitative Dependent Variables. Cambridge: Cambridge University Press.

Greenwood, M. J. 1997. "Internal Migration in Developed Countries.” In M. R. Rosenzweig, and O. Stark, eds., Handbook of Families and Population Economics. Amsterdam: North-Holland.

Ham, John C., Xianghong Li, and Patricia B. Reagan. 2004. Propensity Score Matching: A DistanceBased Measure of Migration and the Wage Growth of Young Men. Ohio State University, Department of Economics, Columbus.

Hanson, Gordon. 1997. "Increasing Returns, Trade, and the Regional Structure of Wages.” Economic Journal 107(440):113-33.

—. Forthcoming. "Globalization, Labor Income, and Poverty in Mexico.” In Ann Harrison, ed., Globalization and Poverty. Chicago: University of Chicago Press and the National Bureau of Economic Research.

Hanson, Gordon, and Antonio Spilimbergo. 1999. "Illegal Immigration, Border Enforcement, and Relative Wages: Evidence from Apprehensions at the U.S.-Mexico Border.” American Economic Review 89(5):1337-57.

Herzog, H. W. Jr, A. M. Schlottmann, and T. P. Boehm. 1993. "Migration as Spatial Job Search: A Survey of Empirical Findings.” Regional Studies 27(4):327-40.

Jones, Richard C. 2001. "Maquiladoras and U.S.-Bound Migration in Central Mexico." Growth and Change 32(2):193-216.

López, R., and M. Schiff. 1998. "Migration and the Skill Composition of the Labour Force: The Impact of Trade Liberalization in LDCs.” Canadian Journal of Economics 31(2):318-36.

Lucas, R. E. B. 1997. “Internal Migration in Developing Countries.” In M. R. Rosenzweig, and O. Stark, eds., Handbook of Families and Population Economics. Amsterdam: North-Holland.

Markusen, J. R., and A. J. Venables. 1997. "The Role of Multinational Firms in the Wage-Gap Debate.” Review of International Economics 5(4):435-51.

Markusen, J. R., and S. Zahniser. 1999. "Liberalization and Incentives for Labor Migration: Theory with Applications to NAFTA.” In R. Faini, J. De Melo, and K. F. Zimmermann, eds., Migration. The Controversies and the Evidence. Cambridge: Cambridge University Press.

Massey, Douglas S., and Kristin E. Espinosa. 1997. "What's Driving Mexico-U.S. Migration? A Theoretical, Empirical, and Policy Analysis.” American Journal of Sociology 102(4):939-99.

McKenzie, David, and Hillel Rapoport. 2004. Network Effects and the Dynamics of Migration and Inequality: Theory and Evidence from Mexico. SCID Working Paper 201. Stanford, CA: Stanford Center for International Development.

Pagano, Marco. 1990. "Imperfect Competition, Underemployment Equilibria, and Fiscal Policy." The Economic Journal 100(401):440-463.

Razin, A., and E. Sadka. 1997. International Migration and International Trade. NBER Working Paper 4230. Cambridge, MA: National Bureau of Economic Research.

Rivera-Batiz, Francisco L. 1986. “Can Border Industries Be a Substitute for Immigration?” American Economic Review 76(2):263-8.

Roback, Jennifer. 1982. "Wages, Rents and the Quality of Life." Journal of Political Economy 90(6):1257-78.

Robertson, Raymond. Forthcoming. "Did NAFTA Increase Labor Market Integration between the United States and Mexico?” World Bank Economic Review 19(3).

Shultz, T. P. 1982. "Lifetime Migration Within Educational Strata in Venezuela: Estimates of a Logistic Model.” Economic Development and Cultural Change 30(3):559-93.

Spencer, P. D. 1989. “Comments on Bover et al.” Oxford Bulletin of Economics and Statistics 51(2):153-7.

Stark, Oded, and J. Edward Taylor. 1991. "Migration Incentives, Migration Types: The Role of Relative Deprivation.” Economic Journal 101(408):1163-78.

Thomas, Alun. 1993. "The Influence of Wages and House Prices on British Interregional Migration Decisions.” Applied Economics 25(9):1261-8. 
Train, Kenneth. 1986. Qualitative Choice Analysis. Theory, Econometrics, and an Application to the Automobile Demand. Cambridge, MA: MIT Press.

Winters, Paul, Alain de Janvry, and Elisabeth Sadoulet. 2001. "Family and Community Networks in Mexico-U.S. Migration.” Journal of Human Resources 36(1):159-84.

Zabin, Carol, and Sallie Hughes. 1995. "Economic Integration and Labor Flows: Stage Migration in Farm Labor Markets in Mexico and the United States." International Migration Review 29(2):395-422. 